\title{
Seeking the views of irregular migrants: Decision-making, drivers and migration journeys
}

\author{
Marie McAuliffe
}

A substantial body of research indicates that a number of complex, interrelated factors impact on the movement of irregular asylum and non-asylum migration flows (Castles, 2013; de Haas, 2011; Havinga \& Böcker, 1999; Koser, 2011; Middleton, 2005; Neumayer, 2004). In some of the literature, the factors related to asylum seeker migration have been characterised as either 'push' or 'pull' factors, both in terms of the decision to migrate as well as choice of destination country (Havinga \& Böcker, 1999; Neumayer, 2004; Zimmermann, 1996). Generally, push factors from the country of origin include: the political and security situation incountry (home and/or host country); the state of the economy, and access to income; the outlook for the future, and in particular the prevailing pessimism (Adhikari, 2013; Hatton, 2011; Theilemann, 2006). Pull factors, on the other hand, include: asylum seeker policies in destination countries; how welcoming destination countries are perceived to be; perceptions of destination countries' acceptance of refugees; the state of

\footnotetext{
1 The author is grateful for research assistance from Simone Gangell and Paul Hayes in the preparation of this chapter.
} 
the economies of destination countries; and the existence of diaspora and communities in destination countries (Koser, 1997; Koser \& Pinkerton, 2002; Neumayer, 2004; Theilemann, 2006; Toshkov, 2012).

There is also a range of 'enabling' factors that act to facilitate flows, and that are less prevalent in the literature. ${ }^{2}$ These enabling factors cannot be characterised by the linear push-pull construct, but act to facilitate or underpin movement. Enabling factors include:

- geography and the ease of travelling to specific destination countries (Havinger \& Böcker, 1999; Monsutti, 2010);

- the ability to travel through transit countries (e.g. facilitative visa arrangements) and proximity to established migration networks (and, in some cases, a related lack of ability to gain visas for lawful entry to destination countries);

- diaspora populations with the ability and resources to assist others in their communities around the world to migrate (Doraï, 2011; Koser \& Pinkerton, 2002);

- an increased ability to self-fund travel, as human development and greater access to resources increases (de Haas, 2010);

- enhanced 'real time' communications technology to provide better information for decision-making both of potential irregular immigrants and people smugglers (e.g. blogs, social media, news reporting of events); and

- a global asylum system that was established decades ago to address a particular set of circumstances, and may not have evolved sufficiently to reflect significant changes in the environment (e.g. refusal of countries to accept the return of their nationals, and the lack of any ability to make countries accept the return of their citizens) (Hamlin, 2012; Hatton, 2011; Jones, 2009).

The number of factors impacting on decision-making highlights the complex nature of irregular migration. It is also important to acknowledge that none of the factors are likely to be static, and some of them can change decisively and rapidly, undoubtedly adding to the complexity of migrant decision-making.

2 One exception being de Haas (2010). 
There is a body of literature on decision-making by asylum seekers and potential asylum seekers; however, there are two important points to note about the research that has been conducted so far on this topic (Koser \& McAuliffe, 2013). First, the focus of this research has been largely limited to 'choice of destination', with very little examination of the decisionmaking processes associated with the decision to leave a country of origin. On the one hand, this is partly due to a view that, in relation to asylum seekers, forced migration is occurring. The associated assumption is that asylum seekers have a lack of agency, thereby effectively rendering research on this aspect of decision-making largely irrelevant (Koser \& Pinkerton, 2002; Robinson \& Segrott, 2002; Spinks, 2013). Forced migration is characterised as being driven by 'push' factors, so that when situations in countries become intolerable asylum seekers are compelled to move across borders.

In addition to the forced migration perspective, the primary focus on choice of destination as opposed to the decision to leave origin countries is likely to be related to the broader policy and political environment of the time. This is especially so in the European context, where much of the research on asylum seeker decision-making has been situated (Brekke \& Aarset, 2009; Neumayer, 2004; Robinson \& Segrott, 2002; van Liempt $\&$ Doomernik, 2006). Neumayer, for example, summarises:

Asylum seekers coming to Western Europe have preferred some destination countries over others. Austria, Germany, Sweden and Switzerland were the main destination countries relative to their population size in the 1980s and 1990s, whereas Finland, Italy, Portugal and Spain took on very few asylum seekers. ... [T] he objective is to explain the choice amongst the various countries on offer as their destination for those asylum seekers coming to Western Europe. I want to explore to what extent one can explain the relative attractiveness of destination countries.

Second, given that much of the research on decision-making is European, it is not able to adequately account for the particularities of the Australian situation, especially Australia's geography and lack of proximity to similar destination countries. That is not to say that the European research is not relevant, for many aspects undoubtedly are. It is, however, prudent to be cautious about aspects of its applicability to the Australia context. In an absence of Australian empirical research, there has been a tendency for researchers and commentators to apply European research findings to the Australian context. In a recent paper published by the Australian Parliamentary Library, for example, Spinks (2013) states that 'decisions 
about where to go are not always made by refugees themselves but rather are often determined, or at least heavily influenced, by others. In some cases, the decision is made by a family member, but for many the destination is chosen by the 'agent' or people smuggler engaged to get them to a place (any place) of safety' (p. 9). The evidence provided by the survey results to be discussed in this chapter calls this into question. Table 5.6, for example, shows that 79 per cent of respondents reported being involved in the final decision to travel to Australia, and that 16 per cent of respondents reported that people who helped with travel (e.g. people smugglers) were involved in the final decision to travel to Australia.

The significant influence of agents is highlighted in European research on asylum seekers' decision-making (Koser, 2008; Robinson \& Segrott, 2002; van Liempt \& Doomernik, 2006). It is possible that the entrenched smuggling networks that have supported irregular migration flows into Europe for decades may render potential migrants less able to exercise agency in terms of where to travel, particularly given the many countries smugglers can ultimately send migrants. This would appear to be less relevant in the Australian context, however, given that Australia is effectively at the 'end of the line'. As highlighted by Koser and McAuliffe (2013), for irregular maritime arrivals (IMAs) in Australia, who have undertaken long and relatively expensive journeys from their origin countries, and transited other countries where they might have remained in an irregular situation ... the choice of Australia for most ... appears to be deliberate' (p. 13). In this sense, it is useful to acknowledge Johansson's distinction between anticipatory refugee movement and acute or spontaneous movements (Johansson, 1990). When examining asylum seeker movement to Australia, much of the movement in recent years has been anticipatory rather than acute. This, in turn, and given the substantial distances travelled from source through (multiple) transit countries to Australia, means that both the decision to leave and the choice of destination are highly relevant topics of research in the Australian context.

Within this context, this chapter provides unique insights into how maritime asylum seekers to Australia contemplated and undertook migration journeys. As the first quantitative empirical research in Australia that has sought the views of IMAs, the study upon which this chapter is based has drawn on the existing European research, but also reflects the different dynamics that the Australian context presents. Seeking irregular migrants' views on the decision-making processes related to 
both the decision to leave and the choice of destination are key aspects of the survey, as are the roles of people other than the migrant in decisionmaking (including agents).

\section{Methods}

The scope of the survey was all adult IMAs who had been granted a protection visa between 6 July, 2011 and 31 December, 2012 (inclusive), and were based in Sydney, Melbourne or Brisbane. This population totalled 4,725 IMAs. The population was defined in order to minimise, as far as possible, problems of recall by limiting the scope to people who had recently travelled as IMAs. That said, issues of recall necessarily remain for this type of research.

IMAs who had not been granted a permanent visa during this period were out of scope. This approach ensured that all people in the survey had certainty about their status in Australia. The scope did not include people found not to be in need of protection, noting that merits and judicial review processes may take considerable periods of time, and a negative primary decision may not reflect a person's final status. In addition, the survey population did not include any persons under the age of 18 due to particular sensitivities concerning interviewing minors. People who were under the age of 18 at the time of travel but had since turned 18 were in scope.

The survey sample was drawn from two of the Department of Immigration and Border Protection's databases: the settlement database and the adult migrant English program database. The survey sample was drawn in two stages. The first group was drawn on 16 April 2013, and this was supplemented by a further group drawn in mid-June 2013.

A stratified sample was selected from the databases. The sample was stratified by citizenship (Afghan, Iranian, Pakistani, Sri Lankan and other ${ }^{3}$ ) and location (New South Wales, Queensland and Victoria). The sampling rates varied between the strata, including because of variability in contact detail accuracy. To gain the same accuracy for estimates for a small population (e.g. Sri Lankans) a much higher sampling rate was required

3 A sufficient subsample of Iraqis was not able to be obtained. Iraqis were included in the 'other' category. 
than for a larger population. The stratification process has not introduced a bias in the population estimates because the responses are appropriately weighted to take these differing sample rates into account. Further details of the survey methodology are outlined in McAuliffe (2013).

\section{Utilising technology to support self-completion}

Due to the challenges inherent in seeking honest, candid information about experiences that may have involved trauma, vulnerability and highrisk behaviour, specific measures were employed as a means of reducing response bias and non-sampling error.

First, the survey was designed as a self-completion survey. The selfcompletion of sensitive questions has been found to increase the level of reporting in a survey by reducing the social desirability effects relative to the administration of the same questions by an interviewer (Tourangeau $\&$ Smith, 1996). Given the sensitive nature of some of the questions, the potential for interviewer bias to affect the results was a significant issue. Interviewer bias can be due to the actual characteristics of the interviewer (e.g. sex, age, perceived social status) or because respondents may be reluctant to reveal beliefs unlikely to be endorsed by an interviewer (Bowling, 2005).

In the IMA survey context, a traditional interviewer survey approach involving bilingual interviewers would be likely to have an impact on bias. This is, in part, due to the specific languages groups required to support an interviewer mode of delivery. Given the history of some IMAs groups, the bilingual interviewers required to conduct the interviews would (for some key citizenship groups) be likely to have their own experiences and views of irregular maritime migration, either due their own personal experiences (they may have themselves been IMAs) or those of their family, friends or other community members. Self-completion allowed for much-reduced interaction by removing the need for an interviewer to conduct the survey and ask questions.

The use of computer-based technology involving self-completion was chosen as it has been found to be effective in eliciting honest, open answers from participants in other surveys involving highly sensitive issues (Tourangeau \& Smith, 1996; Seebregtsa et al., 2009). For example, in a survey on rape in South Africa, participants were asked questions via a tablet computer-based survey on their experiences as both a perpetrator, 
and a victim, of rape (Jewkes, Sikweyiya, Morrell, \& Dunkle, 2009). The results showed that a substantial proportion of men indicated that they themselves had raped, and this finding was in contrast to studies based on other research methodologies.

The survey was conducted using a tablet computer preloaded with the questionnaire translated in the primary language of the participant. The survey was self-completed, rather than interview based, with the questions available in English, Arabic, Dari, Farsi, Hazaragi, Tamil and Urdu. The technology allowed respondents to switch between languages in 'real time'. A 'skip' option allowed participants to skip questions they did not want to answer. The respondent was in control of the pace of the survey and was able to pause, reread a question, or think about an answer, a factor which has been seen to improve the quality of answers in selfadministered questionnaires (Hox, Kef, \& de Leeuw, 2003).

In recognition of potential literacy and technological access issues, bilingual assistants were engaged to provide initial guidance to the participant on how to complete the questionnaire on the tablet computer. The assistants remained available to provide assistance for completion of a question if requested, but did not interview the respondent. This allowed participants to complete the survey anonymously.

The approach involving the provision of bilingual assistants recognised that an unsupported web-based administration would be likely to fail because of the particular characteristics of the population. While this approach may have had an impact on response bias due to the presence of an assistant, the much-reduced interaction (compared to a traditional interviewer) will have undoubtedly had a positive impact on the reporting of sensitive responses. Computer-based self-completion also assists in reducing non-sampling errors, such as missing values and incorrect coding, compared to other survey delivery methods (Bernabe-Ortiz et al., 2008).

There are a number of methodological limitations entailed in the approach that was adopted. Issues of recall, for example, are likely to have an impact on survey results. However, this would equally be the case for other methodologies, such as structured interviews and focus groups. 
Much effort was expended on being able to elicit sensitive information through the use of computer-based self-completion surveying. The approach does not allow, however, for exploration of detailed questioning of aspects of respondents' experiences, such as would be the case through structured interviewing.

\section{Survey results}

A quantitative survey of IMAs, with a specific focus on pre-arrival experiences, was considered an important means to build an aspect of the evidence-base. Surveys of this nature are able to identify patterns, including by determining how widely certain processes are undertaken or what characteristics feature in a particular process (Sayer, 1992, p. 243).

This section provides a summary of the key results of the survey. The results in this chapter are primarily reported at the aggregate level; that is all respondents, rather than subsamples with particular characteristics. Selected results by some citizenship groups (Afghans, Iranians, Pakistanis and Sri Lankans) as well as age have been included to highlight specific demographic differences.

The survey comprised 44 multipart questions on respondents'

- host country experiences;

- circumstances in home and/or host country;

- decisions to leave;

- choice of destination;

- travel to Australia;

- Australian experiences; and

- demographic characteristics.

\section{Host country experiences}

To better understand the experiences of survey participants, it was important to identify their migration histories. People who commenced their journey to Australia from their country of birth would be likely to have a different set of experiences to those who had spent time in host or transit countries, noting that the distinction between 'host' and transit' can be blurry, and is largely based on a time dimension. Respondents who 
indicated they had spent at least 12 months in a country other than their country of birth were asked to respond to a series of questions relating to their experiences in that country.

This subsample comprised 327 respondents, or almost one third of the sample. Discussion of survey results in this section is limited to the subsample, not the entire sample, and has been referred to as 'host' country experiences.

The main host countries identified by respondents were Pakistan (60 per cent) and Iran ( 24 per cent). Other less prominent countries included Indonesia ( 4 per cent), India (3 per cent), and Iraq ( 3 per cent). These results appear to be directly related to the citizenship composition of the 'hosted' subsample: the majority of Afghans ( 57 per cent) indicated they had lived in a country other than their birth country prior to travelling to Australia. Iranian respondents reported very low levels of having lived in a host country (5 per cent). These results accord with the United Nations High Commissioner for Refugees (UNHCR) data on hosted refugee populations (UNHCR, 2013).

These results show that of the four main citizenship groups (Afghans, Iranians, Pakistanis and Sri Lankans), all groups reported 90 per cent or more having been born in their stated country of citizenship. Small proportions of Afghan respondents reported that they were born in Pakistan ( 3 per cent) and Iran ( 2 per cent). Seven per cent of Pakistani citizens reported having been born in Afghanistan. The results indicate, for example, that most Afghan respondents were born in Afghanistan and had been living in a host country prior to travelling to Australia.

The average time spent in a host country was 20.5 years. Eleven per cent had spent 5 years or less in a host country, with almost half ( 44 per cent) having spent more than 20 years in a host country. The vast majority (82 per cent) indicated that they had had no contact with UNHCR while living in a host country, with just 3 per cent having indicated that they had been recognised as a refugee.

The majority of the host country subsample (60 per cent) reported that they had worked illegally while residing in a host country, with 19 per cent having indicated that they worked legally. While not necessarily related, this more or less aligned with the response to questions about their legal status in a host country, with 19 per cent indicating that they had some form of legal status (e.g. registration with UNHCR), while the overwhelming 
majority (79 per cent) advised that they had no legal status. In addition, just over one in 10 indicated they had been deported by their host country at least once. Around 30 per cent of hosted respondents indicated they had travelled back to their country of birth at least once. This was most common among Afghans (31 per cent), and is likely to have involved both voluntary and involuntary movement in light of the deportation results. This is consistent with recognised circulatory migration patterns of Hazaras in the region (Monsutti, 2005, pp. 168-69).

\section{Circumstances in country of origin}

The survey sought respondents' views on three specific aspects of their lives in their country of origin: their 'social proximity' (Fussell \& Massey, 2004) to migration (including direct migration experiences, as well as those of family, friends and others in their communities); the extent of their links to diaspora in Australia; and the problems they faced prior to leaving. For the purposes of this chapter, the term 'origin country' has been used to encompass both 'home' countries (i.e. relevant to people residing in their country of citizenship prior to travel) and 'host' countries (i.e. relevant to people residing in countries other than their country of citizenship). In the survey, 'residence' was defined as being 12 months or more (not including time spent in detention).

\section{Social proximity to migration}

The survey results showed that respondents had, on average, a reasonable social proximity to migration prior to leaving their home or host country to travel to Australia. In other words, social proximity related to the extent to which respondents knew of people who had migrated (or attempted to), or had previously migrated themselves (or attempted to).

Social proximity to migration tended to diminish the closer the respondent was in social terms to the actual migrant group. For example, around a third of respondents indicated that it was common for people to travel to another country for work (32 per cent), and that their ethnic group travelled to other countries for work (34 per cent), compared to friends (17 per cent) and family members (13 per cent) who had migrated for work. 
As shown in Table 5.1, respondents were less sure about being able to answer the more general questions (28-31 per cent chose the 'not sure' option), compared to more specific questions on friends (10 per cent not sure) and family (5 per cent not sure) who had travelled to another country for work.

Table 5.1: Social proximity to migration and travel for work

\begin{tabular}{|l|c|c|c|c|c|}
\hline Measure & $\begin{array}{c}\text { Yes } \\
(\%)\end{array}$ & $\begin{array}{c}\text { No } \\
(\%)\end{array}$ & $\begin{array}{c}\text { Not sure } \\
(\%)\end{array}$ & $\begin{array}{c}\text { No answer } \\
(\%)\end{array}$ & $\begin{array}{c}\text { Total } \\
(\%)\end{array}$ \\
\hline $\begin{array}{l}\text { In [origin country], was it common for people } \\
\text { to travel to another country to find work? }\end{array}$ & 32 & 36 & 31 & 1 & 100 \\
\hline $\begin{array}{l}\text { Did the majority of [your ethnic] community } \\
\text { travel to another country to find work? }\end{array}$ & 34 & 38 & 29 & 1 & 100 \\
\hline $\begin{array}{l}\text { Did you have any friends who travelled to } \\
\text { another country to find work? }\end{array}$ & 17 & 73 & 10 & 1 & 100 \\
\hline $\begin{array}{l}\text { Did you have any family members who } \\
\text { travelled to another country to find work? }\end{array}$ & 13 & 83 & 5 & 1 & 100 \\
\hline $\begin{array}{l}\text { Prior to leaving [origin country], had you } \\
\text { ever applied for a visa to travel to any other } \\
\text { country? }\end{array}$ & 9 & 87 & 3 & 0 & 100 \\
\hline $\begin{array}{l}\text { Prior to leaving [origin country], did you } \\
\text { know of people who had travelled to another } \\
\text { country without a visa? }\end{array}$ & 18 & 68 & 14 & 1 & 100 \\
\hline
\end{tabular}

Source: IMA survey.

When results were examined by the four citizenship groups, there was not much variation in relation to family members who had travelled to another country to find work, nor in relation to applying for visas themselves. There was, however, variation in response to the more general questions about 'ethnic groups' and 'people', with Sri Lankans having reported much higher responses against these two groups (65 per cent and 73 per cent, respectively). Sri Lankans were also less likely to report having had friends who had travelled (2 per cent).

With regard to knowing people who had travelled to other countries without a visa, Afghans were more likely to report this (23 per cent), and Sri Lankans and Pakistanis much less likely ( 2 per cent and 3 per cent, respectively). Afghans reported that the countries people travelled to in these circumstances included Iran, Pakistan, Afghanistan, Turkey and Australia. 


\section{Links to diaspora in Australia}

Another factor with the potential to affect decision-making is the extent to which potential migrants had personal links to family members, friends and others in destination countries. Results showed that around 22 per cent of respondents indicated that they had relatives in Australia before they left their origin country. When other social links to Australia were examined, the results showed that 37 per cent had relatives, friends, friends of relatives/friends or fellow ethnic community members in Australia prior to their departure. When examined by citizenship, Afghans ( 43 per cent) and Pakistanis (38 per cent) were more likely than Iranians (24 per cent) to have links to Australia. Further breakdowns by citizenship group are shown in Figure 5.1.

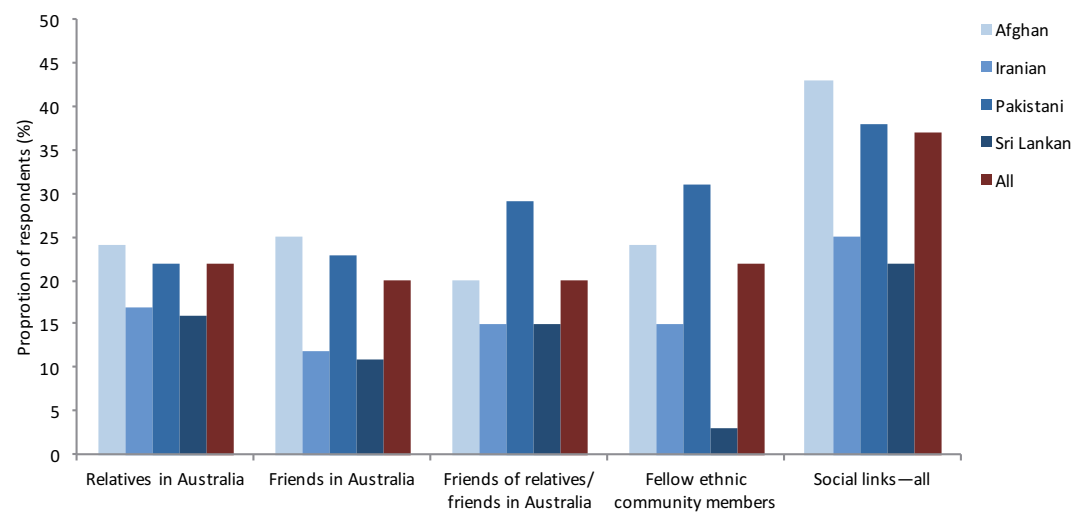

Figure 5.1: Respondents' links to Australia prior to departing origin country

Source: IMA survey $(n=1,008)$.

Note: 'Social links - all' includes relatives, friends, friends of relatives/friends or fellow ethnic community members in Australia.

\section{Prevailing conditions}

When asked about the problems faced in their country of origin, an overwhelming majority of respondents indicated there were many problems facing them, and that these problems were varied in nature and involved protection and non-protection problems. The most prominent problems included ethnic-based discrimination ( 62 per cent), general insecurity (60 per cent), religious discrimination (59 per cent), serious harassment (53 per cent), persecution (51 per cent), political oppression 
(40 per cent), corruption (34 per cent), poor education facilities (30 per cent), lack of job opportunities (27 per cent), unemployment (27 per cent), and poverty (23 per cent).

Respondents' reporting of the top three problems facing them provided further clarity of the severity of the multitude of problems facing them, with protection-based reasons featuring heavily (see Table 5.2). Non-protection reasons also featured, and included general insecurity (32 per cent), widespread violence (10 per cent), unemployment ( 8 per cent), lack of job opportunities ( 7 per cent), and loss of home (6 per cent).

When examined by citizenship, for example, Pakistanis and Afghans were more likely to report religious discrimination than others (85 per cent and 74 per cent respectively), and Sri Lankans and Afghans were more likely to report persecution on the basis of ethnicity ( 89 per cent and 80 per cent, respectively). Sri Lankans were also much more likely than others to report 'eviction/loss of home/nowhere to live' as a problem (69 per cent). Further analysis of these results is likely to reveal a complex picture that will vary by citizenship and ethnicity. This would be further enhanced through the completion of future surveys so that changes over time could be analysed.

Table 5.2: Problems faced by respondents in country of origin prior to travel: Protection and non-protection

\begin{tabular}{|l|c|c|c|c|c|}
\hline & $\begin{array}{c}\text { ALL } \\
(\%)\end{array}$ & $\begin{array}{c}\text { Afghans } \\
(\%)\end{array}$ & $\begin{array}{c}\text { Iranians } \\
(\%)\end{array}$ & $\begin{array}{c}\text { Pakistanis } \\
(\%)\end{array}$ & $\begin{array}{c}\text { Sri Lankans } \\
(\%)\end{array}$ \\
\hline Protection \\
\hline $\begin{array}{l}\text { Discrimination against } \\
\text { [ethnicity] people }\end{array}$ & 62 & 80 & 22 & 66 & 89 \\
\hline Religious discrimination & 59 & 74 & 42 & 85 & 60 \\
\hline Serious harassment & 53 & 59 & 52 & 24 & 72 \\
\hline Persecution & 51 & 55 & 41 & 42 & 71 \\
\hline Political oppression & 40 & 32 & 57 & 41 & 73 \\
\hline Torture & 39 & 39 & 41 & 28 & 81 \\
\hline Non-protection 1 & 60 & 63 & 54 & 54 & 83 \\
\hline General insecurity & 39 & 38 & 36 & 38 & 68 \\
\hline Widespread violence & 27 & 20 & 27 & $3^{*}$ & $16^{*}$ \\
\hline Unemployment & 30 & 29 & 20 & $13^{*}$ & 30 \\
\hline Poor education facilities & 27 & 18 & 29 & $2^{*}$ & 26 \\
\hline Lack of job opportunities & &
\end{tabular}




\begin{tabular}{|l|c|c|c|c|c|}
\hline & $\begin{array}{c}\text { ALL } \\
(\%)\end{array}$ & $\begin{array}{c}\text { Afghans } \\
(\%)\end{array}$ & $\begin{array}{c}\text { Iranians } \\
(\%)\end{array}$ & $\begin{array}{c}\text { Pakistanis } \\
(\%)\end{array}$ & $\begin{array}{c}\text { Sri Lankans } \\
(\%)\end{array}$ \\
\hline $\begin{array}{l}\text { Eviction/loss of home/ } \\
\text { nowhere to live }\end{array}$ & 20 & 18 & 8 & $<1^{*}$ & 69 \\
\hline Corruption & 34 & 31 & 38 & $17^{*}$ & 42 \\
\hline Poverty & 23 & 18 & 16 & $2^{*}$ & 25 \\
\hline Poor health facilities & 22 & 22 & 10 & $3^{*}$ & 38 \\
\hline Other & 2 & $1^{*}$ & $2^{*}$ & $1^{*}$ & $<1^{*}$ \\
\hline Other & $<1^{*}$ & $<1^{*}$ & $<1^{*}$ & 0 & 0 \\
\hline Threat to life & & & & \\
\hline Prefer not to say & $<1^{*}$ & 0 & $<1^{*}$ & 0 & 0 \\
\hline
\end{tabular}

Source: IMA survey. $(n=1,008)$. Multiple response question.

Note: (1) It is possible that some 'non-protection' factors (e.g. 'eviction/loss of home/ nowhere to live') could be protection-related, depending on the exact nature of claims made. For the purposes of this chapter, these factors have been interpreted as being non-protection factors. (2) These citizenship groups have low sample sizes and results for these groups should be treated with caution. (3) 'Threat to life' was coded based on open responses from the 'Other' field. For the purposes of this analysis, it is considered as a protection factor. Estimates based on less than 20 unweighted responses have been asterisked.

\section{Decision-making}

To better understand the range of factors involved in irregular migration decision-making processes, the survey asked questions about both the decision to leave and the choice of destination. It asked respondents about their involvement, the involvement of other people, and the sources of information used in these decisions. The survey also asked respondents about the reasons they left their country of origin to travel to Australia, and about any specific events that triggered their departure. Noting that all respondents had been granted protection in Australia, responses related to different forms of persecution ranked highly. The range of reasons for leaving selected by respondents, however, appears to indicate the complexity involved in the decision to leave, particularly in light of the prevalence of both protection and non-protection reasons for leaving origin countries.

Overall, responses showed that both 'push' and 'pull' factors were taken into account in decision-making, and that both 'protection' and 'nonprotection' reasons for movement applied. Responses to questions about people involved the decision to leave and choice of destination indicate that there are some differences in these decision-making processes, 
including in relation to the involvement of specific groups of people such as friends and family in origin countries, and people who help with travel (e.g. people smugglers). The differences in results are discussed below.

\section{Reasons for leaving country of origin}

The most common reasons respondents selected for leaving their country of origin were religious persecution (51 per cent), persecution against people of the respondent's ethnicity (52 per cent) and general insecurity/ conflict (42 per cent). General persecution (32 per cent), political persecution ( 25 per cent), an issue with the origin country's authorities (16 per cent) and persecution against women (14 per cent) also featured (see Table 5.3).

Many respondents also reported 'pull' factors among their reasons for leaving to travel to Australia, particularly perceptions of Australia's attitude towards asylum seekers and refugees, with 30 per cent selecting 'Australia treats asylum seekers well' and 23 per cent selecting 'Australia accepts refugees'.

Twenty-four per cent responded that they left to travel to Australia for 'a better life'. This response option was imprecise in that it is likely to refer to a range of protection and/or non-protection reasons, and may also encompass both 'push' and/or 'pull' factors. However, it was included in the survey because it is a phrase that is often used by migrants themselves. Further analysis of this variable against other variables is likely to be of interest.

Of the non-protection reasons, the most common reason for leaving was general insecurity/conflict (42 per cent). Other non-protection reasons included 'better education services' ( 15 per cent), 'better health services' ( 9 per cent), 'lack of economic opportunity' ( 9 per cent), 'to get Australian citizenship' ( 9 per cent), 'better housing' ( 8 per cent) and 'to work' (7 per cent).

Consistent with results concerning the problems faced in origin countries, when the reasons for leaving were examined by citizenship, Pakistanis and Afghans were more likely to report religious persecution than others (82 per cent and 68 per cent, respectively), and Sri Lankans and Afghans were more likely to report persecution on the basis of ethnicity (84 per cent 
and 69 per cent, respectively). Sri Lankans and Iranians were also more likely than other groups to report political persecution (70 per cent and 49 per cent, respectively) as a reason for leaving.

Respondents' reporting of the top three reasons for leaving provided further clarity, with protection-based reasons featuring heavily. Nonprotection reasons also featured, and included general insecurity (30 per cent), 'Australia treats asylum seekers well' (15 per cent), 'for a better life' (13 per cent), issue with the country's authorities (10 per cent), and better education services (7 per cent).

Table 5.3: Reasons for leaving country of origin: Protection and non-protection

\begin{tabular}{|c|c|c|c|c|c|}
\hline & $\begin{array}{l}\text { ALL } \\
(\%)\end{array}$ & $\begin{array}{c}\text { Afghans } \\
(\%)\end{array}$ & $\begin{array}{c}\text { Iranians } \\
(\%)\end{array}$ & $\begin{array}{c}\text { Pakistanis }{ }^{2} \\
(\%)\end{array}$ & $\begin{array}{c}\text { Sri Lankans }{ }^{2} \\
(\%)\end{array}$ \\
\hline \multicolumn{6}{|l|}{ Protection } \\
\hline $\begin{array}{l}\text { Persecution against [Ethnicity] } \\
\text { people }\end{array}$ & 52 & 69 & 18 & 63 & 84 \\
\hline Religious persecution & 51 & 68 & 33 & 82 & 45 \\
\hline General persecution & 32 & 28 & 35 & $24^{*}$ & 64 \\
\hline Political persecution & 25 & 11 & 49 & $23^{*}$ & 70 \\
\hline Australia accepts refugees & 23 & 24 & 12 & $25^{\star}$ & $19^{*}$ \\
\hline $\begin{array}{l}\text { Persecution based against } \\
\text { women }\end{array}$ & 14 & 7 & 21 & $6^{*}$ & 59 \\
\hline \multicolumn{6}{|l|}{ Non-protection ${ }^{1}$} \\
\hline General insecurity/conflict & 42 & 41 & 40 & 43 & 69 \\
\hline $\begin{array}{l}\text { Australia treats asylum } \\
\text { seekers well }\end{array}$ & 30 & 30 & 21 & 32 & 20 \\
\hline For a better life & 24 & 18 & 24 & $13^{*}$ & $12^{*}$ \\
\hline $\begin{array}{l}\text { Issue with the country's } \\
\text { authorities }\end{array}$ & 16 & 7 & 32 & $1^{*}$ & 40 \\
\hline For better education services & 15 & 12 & 14 & $4^{*}$ & $8^{*}$ \\
\hline To get Australian citizenship & 9 & $5^{\star}$ & $3^{*}$ & 0 & $4^{\star}$ \\
\hline To work & 7 & $4^{\star}$ & $4^{*}$ & $1^{*}$ & $2^{*}$ \\
\hline For better health services & 9 & 5 & $5^{*}$ & $1^{*}$ & $2^{*}$ \\
\hline Lack of economic opportunity & 9 & 5 & 11 & $2^{*}$ & $14^{*}$ \\
\hline For better housing & 8 & 6 & $2^{*}$ & $2^{*}$ & $<1^{*}$ \\
\hline To join family/community & 3 & $2^{*}$ & $<1^{*}$ & 0 & $3^{*}$ \\
\hline Australia is safe & $<1^{*}$ & $<1^{*}$ & 0 & 0 & $<1^{*}$ \\
\hline
\end{tabular}




\begin{tabular}{|c|c|c|c|c|c|}
\hline & $\begin{array}{l}\text { ALL } \\
(\%)\end{array}$ & $\begin{array}{c}\text { Afghans } \\
(\%)\end{array}$ & $\begin{array}{c}\text { Iranians } \\
(\%)\end{array}$ & $\begin{array}{c}\text { Pakistanis }{ }^{2} \\
(\%)\end{array}$ & $\begin{array}{c}\text { Sri Lankans } \\
(\%)\end{array}$ \\
\hline \multicolumn{6}{|l|}{ Other } \\
\hline I don't know, I was a child & $<1^{*}$ & $<1^{*}$ & $<1^{*}$ & 0 & 0 \\
\hline Other & 3 & $3^{*}$ & $2^{*}$ & $1^{*}$ & 0 \\
\hline Threat to life $^{3}$ & 3 & $4^{*}$ & 0 & $3^{*}$ & 0 \\
\hline None of these & 3 & $3^{*}$ & $5^{\star}$ & 0 & $3^{*}$ \\
\hline
\end{tabular}

Source: IMA survey $(n=1,008)$. Multiple response question.

Note: (1) It is possible that some 'non-protection' factors (e.g. 'issue with country's authorities') could be protection-related, depending on the exact nature of claims made. For the purposes of this chapter, these factors have been interpreted as being non-protection factors. (2) These citizenship groups have low sample sizes and results for these groups should be treated with caution. (3) 'Threat to life' was coded based on open responses from the 'Other' field. For the purposes of this analysis, it is considered as a protection factor. Estimates based on less than 20 unweighted responses have been asterisked.

The vast majority of respondents ( 85 per cent) indicated that they faced both protection and non-protection-related problems in their country of origin and/or left their origin country for both protection and nonprotection reasons (see Table 5.4).

When examined by citizenship, the results show that there was not a great deal of variation between citizenship groups, the exception being Sri Lankan respondents, who were more likely to have reported both protection and non-protection factors (96 per cent).

Table 5.4: Problems faced in origin country and/or reasons for leaving country of origin: Protection and non-protection factors ${ }^{1}$

\begin{tabular}{|l|c|c|c|c|c|}
\hline & $\begin{array}{c}\text { ALL } \\
(\%)\end{array}$ & $\begin{array}{c}\text { Afghans } \\
(\%)\end{array}$ & $\begin{array}{c}\text { Iranians } \\
(\%)\end{array}$ & $\begin{array}{c}\text { Pakistanis } \\
(\%)\end{array}$ & $\begin{array}{c}\text { Sri Lankans }^{3} \\
(\%)\end{array}$ \\
\hline $\begin{array}{l}\text { Both protection and non- } \\
\text { protection }\end{array}$ & 85 & 86 & 81 & 85 & 96 \\
\hline Protection only & 9 & 11 & 8 & $15^{\star}$ & 0 \\
\hline Non-protection only ${ }^{2}$ & 3 & $1^{*}$ & $4^{\star}$ & 0 & $2^{*}$ \\
\hline Other/none/no answer & 3 & $2^{*}$ & $7^{\star}$ & 0 & $2^{*}$ \\
\hline Total & 100 & 100 & 100 & 100 & 100 \\
\hline
\end{tabular}

Source: IMA survey $(n=1,008)$.

Notes: (1) Protection problems and reasons included: all forms of persecution, religious discrimination, ethnic discrimination, serious harassment, political oppression, torture, 'Australia accepts refugees', 'threat to life'. Non-protection problems and reasons included: lack of economic/job opportunity; unemployment; general insecurity/conflict; widespread violence, corruption, poverty, for better housing; eviction/loss of home; to work; to join family/community; poor/better health services; poor/better education services; for a better 
life; issue with country's authorities; to get Australian citizenship; 'Australia treats asylum seekers well'. (2) It is possible that some 'non-protection' reasons could be protectionrelated, depending on the exact nature of claims made. For the purposes of the survey, the problems/reasons in note 2 have been interpreted as being non-protection. (3) These citizenship groups have low sample sizes and results for these groups should be treated with caution. Estimates based on less than 20 unweighted responses have been asterisked.

\section{Departure triggers}

Acknowledging that decision-making factors are not static and can change decisively and rapidly, the survey asked respondents whether any particular events triggered their departure. The results suggest that while the underlying reasons respondents decided to leave may have been present for a period of time, in most instances a specific incident triggered their departure.

Sixty-eight per cent responded that a significant security threat or incident triggered their departure. Events affecting respondents' family and friends, namely a threat against family/children (31 per cent) and the loss of a close family member/friend (18 per cent) ranked second and third respectively.

The next most common responses were the imminent threat of deportation (18 per cent), loss, or threat of losing home or shelter (14 per cent) and loss, or threat of losing job or income (11 per cent). In relation to the role of people smugglers, three per cent of respondents answered that being approached by an agent (e.g. people smuggler) was a trigger.

\section{People involved in the decision to leave}

The responses to questions about the people involved in the final decision to leave indicated that friends and/or family in the country of origin played an important role and that, to a lesser extent, people smugglers were involved. A not insubstantial proportion of respondents indicated that they themselves were not involved in the final decision to leave (12 per cent). Eighty-two per cent responded that they were themselves involved in the final decision. When examined by citizenship, Iranians were more likely to not have been involved (19 per cent), along with Afghans (11 per cent) compared to Sri Lankans (4 per cent). In light of the survey results on who respondents travelled with-which show that Iranian respondents were more likely to have travelled in family groupsthe higher Iranian results may be related to the age and/or sex of the respondents. 
Responses to questions on the involvement of friends and family in the decision to leave varied with respect to location. Forty per cent indicated that friends/family in their country of origin were involved in the decision, with only 6 per cent having indicated that friends/family in other countries were involved and 5 per cent that friends/family in Australia were involved.

Finally, 11 per cent of respondents indicated that people who helped them travel (e.g. people smugglers) were involved in the decision to leave. Sri Lankans were more likely to report the involvement of people smugglers (20 per cent).

\section{The choice of destination}

The survey sought respondents' perspectives on Australia as a destination country and the reasons they travelled to Australia, with questions about their consideration of destination countries, as well as the sources of information and methods of access they used when making the decision.

When asked to select the countries they considered travelling to, 47 per cent of respondents selected Australia, and 33 per cent selected the option, 'I did not consider any particular countries'. Canada and the UK (6 per cent and 5 per cent, respectively) were the next most common responses.

Respondents who selected Australia were then asked about the reasons they considered travelling to Australia over other possible countries (see Table 5.5). The most common responses were that 'Australia was accepting refugees' (65 per cent) and that it 'does not return refugees' ( 46 per cent). The responses 'other countries were not accepting refugees' (18 per cent) and 'other countries were returning refugees' (17 per cent) ranked fourth and fifth respectively. The third ranked response was 'because my family would be able to follow me to Australia' (24 per cent). Table 5.5 provides the full list of responses.

The survey also asked respondents about the main reasons they ended up travelling to Australia from their origin country (as opposed to selecting Australia relative to another country). The attractiveness of Australia appeared to lessen: 'Australia was accepting refugees' dropped to 33 per cent and 'Australia does not return refugees' dropped to 22 per cent, although they were still highly ranked. Despite similarity to the reasons given for 
considering Australia, the results to this question indicate that there are different dynamics involved in this aspect of decision-making. Forty per cent indicated that none of the response options applied, indicating that the question was not sufficiently tested and essentially failed. While it is extremely difficult to speculate about the reasons that did apply and were not reflected in the survey question, it is possible that the impact of people assisting with travel (e.g. people smugglers) could be a reason, noting that respondents indicated that these people were more involved in the decision about where to migrate than the decision to leave the origin country.

Table 5.5: Respondents' consideration of Australia as a destination country and reasons for travelling to Australia

\begin{tabular}{|c|c|c|}
\hline Reason & $\begin{array}{l}\text { Why did you } \\
\text { consider travelling to } \\
\text { Australia over other } \\
\text { countries? }\end{array}$ & $\begin{array}{c}\text { What were the main } \\
\text { reasons you ended } \\
\text { up travelling to } \\
\text { Australia? }\end{array}$ \\
\hline Australia was accepting refugees & 65 & 31 \\
\hline Australia does not return refugees & 46 & 22 \\
\hline $\begin{array}{l}\text { Because my family would be able to } \\
\text { follow me to Australia }\end{array}$ & 24 & 9 \\
\hline $\begin{array}{l}\text { Other countries were not accepting } \\
\text { refugees }\end{array}$ & 18 & 8 \\
\hline Other countries were returning refugees & 17 & 7 \\
\hline There is work in Australia & 13 & 4 \\
\hline $\begin{array}{l}\text { Because it is easier to travel to Australia } \\
\text { than other countries }\end{array}$ & 14 & 7 \\
\hline To be with my family & 8 & 2 \\
\hline To be with [ethnicity] people & 6 & 4 \\
\hline I did not have family in other countries & 5 & 4 \\
\hline I did not have friends in other countries & 4 & 3 \\
\hline Australia is safe & 3 & 2 \\
\hline To be with friends & 3 & 1 \\
\hline $\begin{array}{l}\text { [Ethnicity] people are not in other } \\
\text { countries }\end{array}$ & 2 & 1 \\
\hline Threat to life & 1 & 3 \\
\hline Other & 3 & 6 \\
\hline None of these & 11 & 40 \\
\hline No answer & 0 & 5 \\
\hline
\end{tabular}

Source: IMA survey ( $n=454$ to 554$)$. 
These responses indicate there would be value in further research into Australias position as a destination country in the complex global migration context, including how Australia is perceived in comparison to other destination countries.

Using questions structured in the same way as those about the decision to leave (see the section on 'reasons for leaving country of origin', above) the survey asked about the people involved in the choice of destination, including the role of friends and family in origin countries, diaspora and agents (e.g. people smugglers).

Seventy-nine per cent responded that they were themselves involved in the final decision that Australia would be the final destination, while 13 per cent responded that they were not involved. This is similar to the result on respondent involvement in the final decision to leave (12 per cent were not involved), and again Iranians were more likely to have indicated that they were not involved in the destination decision (19 per cent).

The involvement of friends/family in the decision again varied with respect to location. Twenty-nine per cent responded that friends/family in origin countries were involved in the final decision, while 6 per cent responded that friends/family in Australia were involved and 4 per cent responded that friends/family in other countries were involved.

Overall, 15 per cent of respondents indicated that people who helped them travel (e.g. people smugglers) were involved in the decision that Australia would be their final destination. Iranians were more likely to have reported the involvement of these people (25 per cent), and Afghans less likely (9 per cent).

\section{Sources of information about Australia}

Respondents most commonly reported that they relied on friends and family in their country of origin (23 per cent) and people who helped them travel (e.g. people smugglers) (15 per cent) for information about Australia, prior to making the final decision that Australia would be their final destination. Only 5 per cent responded that they relied on social media (e.g. Facebook) for information, with 47 per cent indicating that they did not use social media. Similar to other results, Iranian respondents (24 per cent) were more likely to have reported reliance on people who helped them travel (e.g. people smugglers). 
In relation to information sources from Australia, 12 per cent of respondents reported relying on official information from the Australian Government, and 7 per cent on friends/family in Australia.

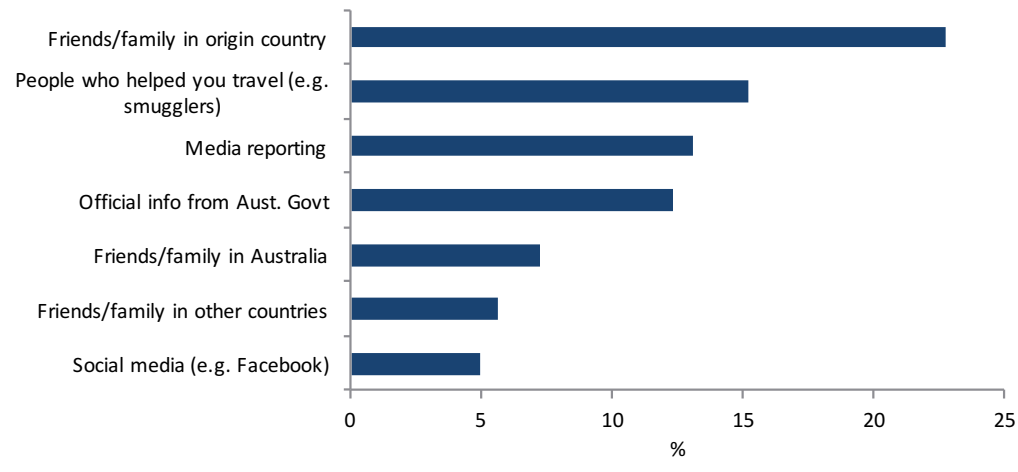

Figure 5.2: Sources of information relied upon when making the final decision that Australia would be the destination

Source: IMA survey $(n=1,008)$.

\section{Differences in decision-making processes: The decision to leave and choice of destination}

The survey responses indicated that there were some differences in decision-making processes in relation to the decision to leave the country of origin and the choice of destination. For example, friends/family in origin countries were more likely to have been involved in the decision to leave than they were in the choice of destination, while the opposite is true for people who helped the respondents to travel (e.g. people smugglers).

Table 5.6: People involved in decision-making processes

\begin{tabular}{|l|c|c|}
\hline & $\begin{array}{c}\text { Decision to leave } \\
\text { origin country (\%) }\end{array}$ & $\begin{array}{c}\text { Decision to go to } \\
\text { Australia (\%) }\end{array}$ \\
\hline Respondent & 82 & 79 \\
\hline Friends/family in origin country & 40 & 28 \\
\hline Friends/family in Australia* & 5 & 6 \\
\hline Friends/family in other countries & & 4 \\
\hline $\begin{array}{l}\text { People who helped with travel (e.g. people } \\
\text { smugglers) }^{*}\end{array}$ & 11 & 15 \\
\hline
\end{tabular}

Source: IMA survey $(n=1,008)$.

Note: *Some respondents indicated that some circumstances did not apply (e.g. they did not have family/friends in Australia). The percentages are based on the total responses, including responses that indicated that circumstances did not apply. 
There were also some differences in decision-making processes when individual and collective decision-making was examined. As shown in Figure 5.3, a higher proportion of respondents indicated that they made the decision to travel to Australia by themselves compared to the decision to leave the country of origin.

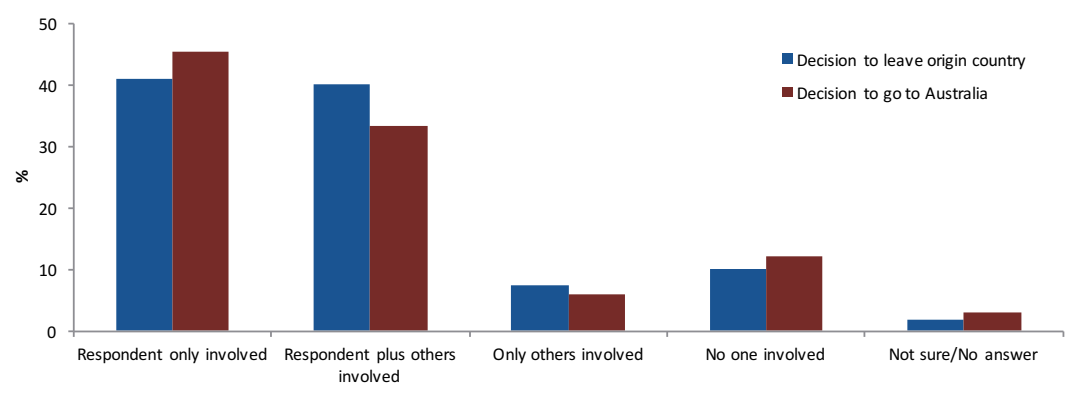

Figure 5.3: Individual and collective decision-making: Decision to leave and decision to travel to Australia

Source: IMA survey $(n=1,008)$.

Additional research into the circumstances in which people are not involved in the final decision to leave would provide a better understanding of the role of collective decision-making on migration, and may also provide insights into issues of potential vulnerability involved in irregular migration.

\section{Travelling to Australia}

The survey also explored respondents' experiences of their journey to Australia. The questions examined connections to a range of different groups, such as people who had helped them travel (e.g. people smugglers), as well as practices they adopted en route and how safe these practices made respondents feel while travelling. Almost two thirds of respondents travelled without friends or family, and around 30 per cent reported having travelled with family. There was significant variation by citizenship, as shown in Figure 5.4, with Iranians much more likely to have reported having travelled with family ( 54 per cent) compared to other citizenship groups: Afghans (6 per cent); Pakistanis (11 per cent); Sri Lankans (19 per cent). 


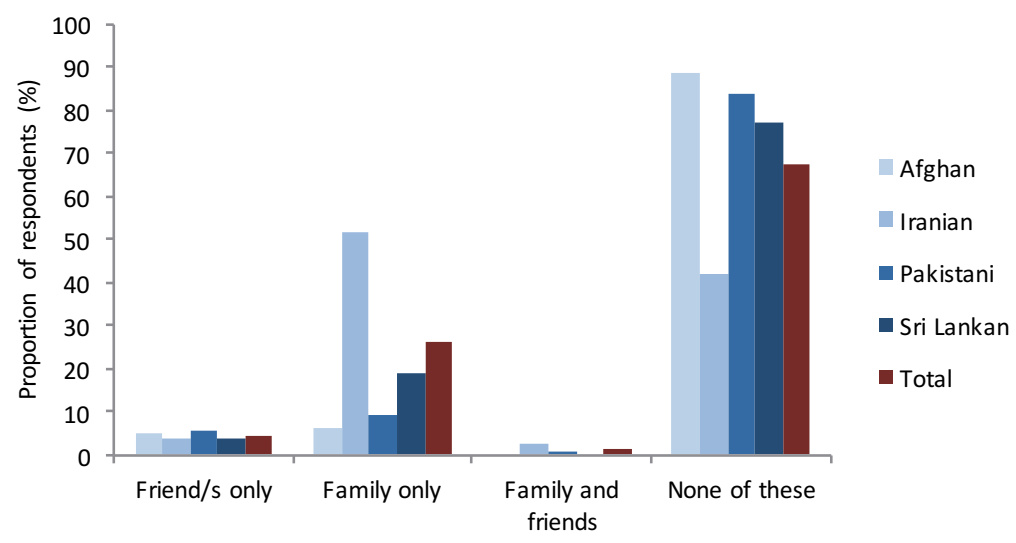

Figure 5.4: Respondents' travelling companions

Source: IMA survey $(n=1,008)$.

In terms of assistance respondents received to travel to Australia, agents (e.g. people smugglers) previously unknown to the respondent provided the most help ( 43 per cent of respondents received help). Friends and family in origin countries also provided assistance, although there was variation by citizenship, with Pakistanis and Sri Lankans reporting greater assistance from this group ( 45 per cent and 41 per cent respectively; see Figure 5.5).

Assistance was also provided by agents (e.g. people smugglers) previously known to the respondent, although this was more common for Iranians. Respondents indicated that family/friends in Australia and other countries did not tend to help with travel (6 per cent and 3 per cent respectively).

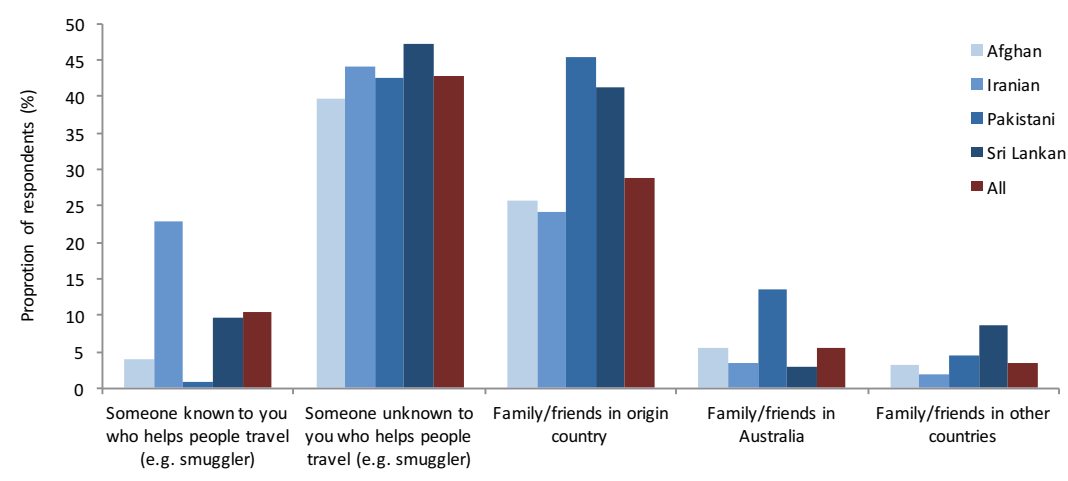

Figure 5.5: Assistance respondents received to travel to Australia Source: IMA survey $(n=1,008)$. 
The average amount invested in travel to Australia was around USD12,600, with some marginal variation by citizenship: USD13,500 for Afghans; USD12,200 for Iranians; USD11,000 for Pakistanis; USD9,200 for Sri Lankans. Travel was predominantly funded by respondents' immediate families (including self-funding) (82 per cent); 10 per cent had been funded by family/friends in their origin country, and 2 per cent by family/friends in Australia. Eighteen per cent indicated that they (or their families) were still in debt, although Sri Lankans were more likely to report this (36 per cent).

Most respondents (91 per cent) indicated that they had travelled through Indonesia on their way to Australia; 55 per cent transited Malaysia, 23 per cent transited Thailand, 13 per cent transited Pakistan and 8 per cent transited the United Arab Emirates. Only 3 per cent of respondents indicated that they had travelled directly to Australia. When examined by citizenship, as shown in Figure 5.6, many Pakistanis and Afghans indicated that they had travelled to Australia via multiple transit countries, whereas nearly half of the Sri Lankans indicated that they had travelled directly.

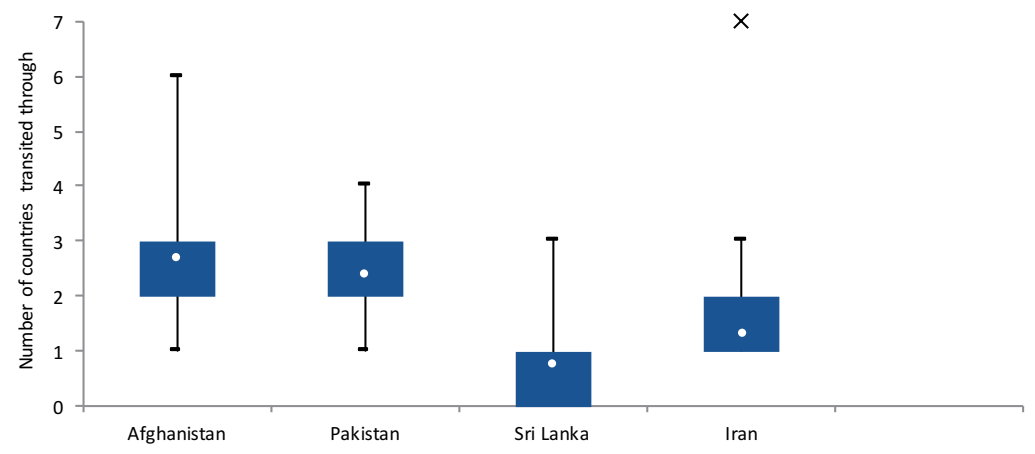

Figure 5.6: Number of transit countries by citizenship

Source: IMA survey $(n=1,008)$.

Notes: $\bullet$ is the mean number of transit countries; $\times$ refers to an outlier. The box represents the interquartile range (the 25 th to 75 th percentile). The black line represents the minimum and maximum values.

\section{Practices en route}

Consistent with anecdotal information, the journey to Australia, for many respondents, involved crossing multiple borders, spending time in countries with no legal status and relying on strangers to progress the 
next stage of their journey. This suggests a high degree of risk, fear and uncertainty for those who made the journey, as evident from the survey results. Fifty-four per cent of all respondents indicated that they were smuggled across other countries' borders at some stage of their journey. When the results are examined by citizenship group, substantial differences emerged, with 73 per cent of Afghans and 70 per cent of Pakistanis having reported being smuggled. The results were much lower for Iranians (24 per cent) and Sri Lankans (4 per cent), noting that around half of the Sri Lankan respondents reported having travelled directly to Australia.

Nineteen per cent of respondents reported having paid bribes to officials; however, this was much higher among Iranians (39 per cent) compared to other citizenship groups (10 per cent for Pakistanis and Afghans).

Many respondents (41 per cent) reported having travelled on a false passport at some stage during their journey to Australia (a further 17 per cent were not sure if their passport was valid or false), with 74 per cent of those indicating that using a false passport had made them feel very or quite unsafe. In contrast, and not surprisingly, of those who had valid visas to enter transit countries (39 per cent), the majority reported that this had made them feel very or quite safe ( 62 per cent).

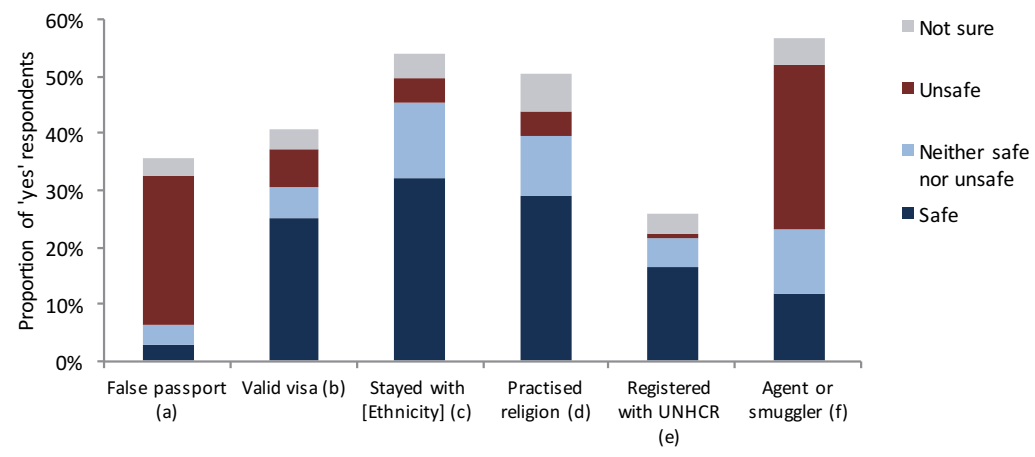

Figure 5.7: Aspects of feeling safe during journey to Australia

Source: IMA survey $(n=1,008)$.

Notes: (a) Used a false passport during your journey to Australia ( $n=357)$; (b) Had a visa to validly enter a transit country during your journey to Australia ( $n=399)$; (c) Stayed with [Ethnicity] people during your journey to Australia $(n=537)$; (d) Able to practice your religion in transit countries during your journey to Australia $(n=501)$; (e) Registered with UNHCR during your journey to Australia ( $n=257)$; ( $f$ ) Used the services of someone who helps people to travel during your journey to Australia $(n=557)$. 
Some practices appeared to increase the sense of safety during the journey, such as contact with members of their ethnic community (59 per cent felt very or quite safe), or practising their religion ( 57 per cent felt very or quite safe). Just over one quarter of respondents registered with UNHCR during the journey to Australia. Overall this provided a sense of safety (63 per cent felt very or quite safe). Four per cent of those registered with UNHCR reported this had made them feel unsafe. A majority of respondents (56 per cent) indicated that they had used the services of someone who helps people travel (e.g. people smuggler) during their journey. Around half of these respondents indicated that this had made them feel quite or very unsafe during their journey to Australia.

\section{Australian experiences}

The survey sought the views of respondents on whether they engaged in specific activities after arriving in Australia, including communicating with family and friends in various locations, travelling back to their origin country to visit, and providing remittances. Forty per cent indicated that they did not undertake any such activities, and 9 per cent chose not to respond. The most prevalent activity reported was the provision of money to family and/or friends in their home country (35 per cent), with 7 per cent having indicated that they send money to people in other countries.

In reflecting on the journey to Australia, the vast majority of respondents indicated that the journey to Australia was more difficult or much more difficult (83 per cent) than they had expected-see Figure 5.8. Very few respondents ( 1 per cent) indicated than the journey was easier or much easier than expected. This accorded with respondents reported experiences en route, particularly in relation to how unsafe they felt during their journey when using a people smuggler(s). The implications of the disparity between potential migrants' views of what the migration journey is likely to entail compared to the reality of the journey are potentially profound.

It would be useful to examine this issue in more detail, noting there was not significant variation between citizenship groups, the notable exception being Sri Lankans, 96 per cent of whom reported that the journey was much more difficult than expected (with another 3 per cent reporting it was more difficult than expected). Further analysis of survey data, 
supplemented with qualitative research, would enhance the understanding of migrants' journeys, which in turn would assist in enhancing informed choice of migrants and reducing vulnerability en route.

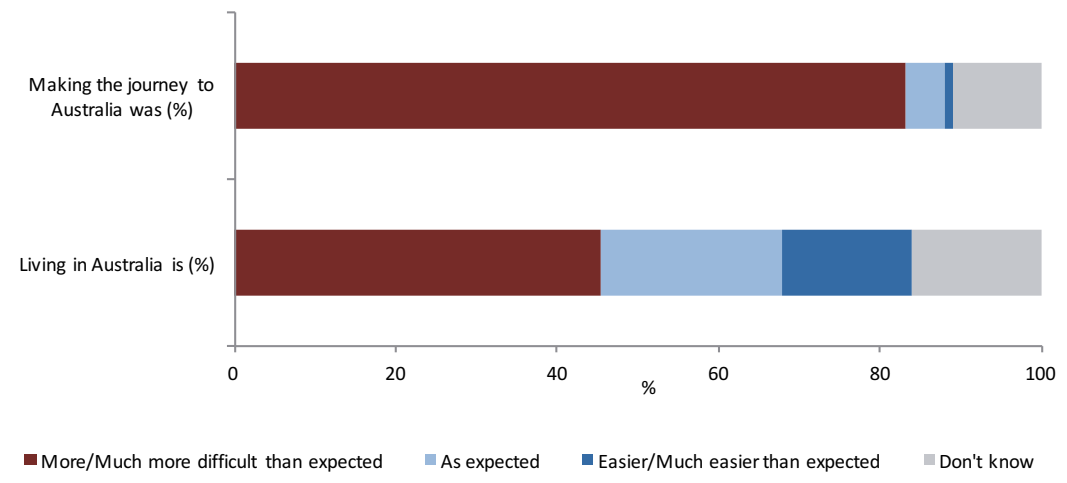

Figure 5.8: Experiences of the journey to, and life in, Australia Source: IMA survey $(n=1,008)$.

A slightly higher proportion of respondents ( 45 per cent) found that living in Australia was more difficult or much more difficult than expected compared to those that found it as expected, easier or much easier (39 per cent). There was significant variation by citizenship group. As shown in Figure 5.9, Sri Lankans were more likely to have reported life in Australia as being easier or much easier ( 80 per cent) compared to Iranians ( 4 per cent), Afghans ( 15 per cent) and Pakistanis (25 per cent).

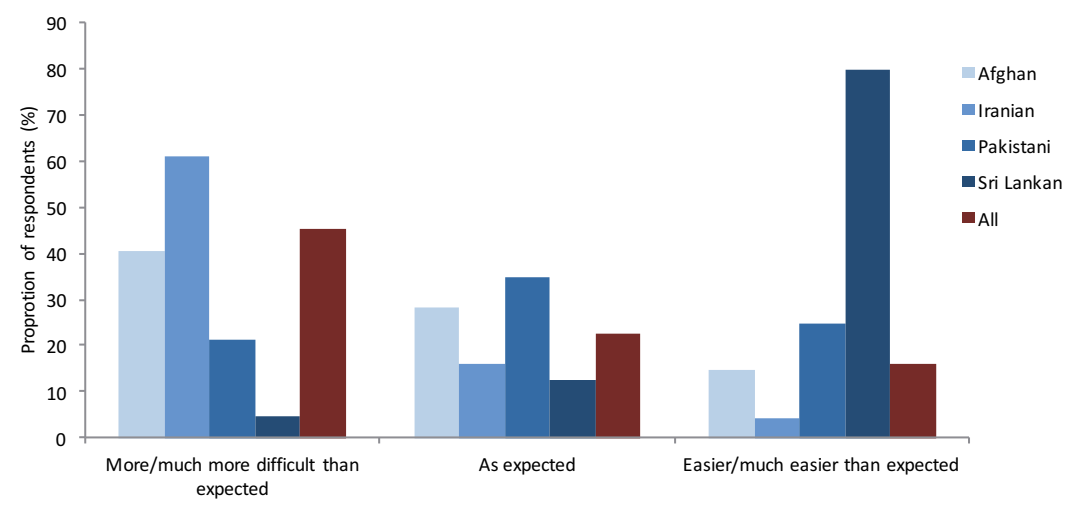

Figure 5.9: Respondents' perceptions of living in Australia

Source: IMA survey $(n=1,008)$. 
The fact that most Sri Lankans found living in Australia easier than expected may be related to their English language ability. Eightyone per cent of Sri Lankan respondents stated that English was their primary language, compared with less than 1 per cent for Afghans, and 5 per cent for both Iranians and Pakistanis. Figure 5.10 shows that there is a correlation between respondents who perceived living in Australia to be easier than expected and those who stated that English is one of their primary languages. The survey asked respondents to list their 'primary language(s)'. It did not take into account actual competency levels, or those who spoke English but did not consider English as a primary language. Examination of respondents' perceptions of life in Australia showed no correlation with the existence of social links to Australia, or being employed in Australia.

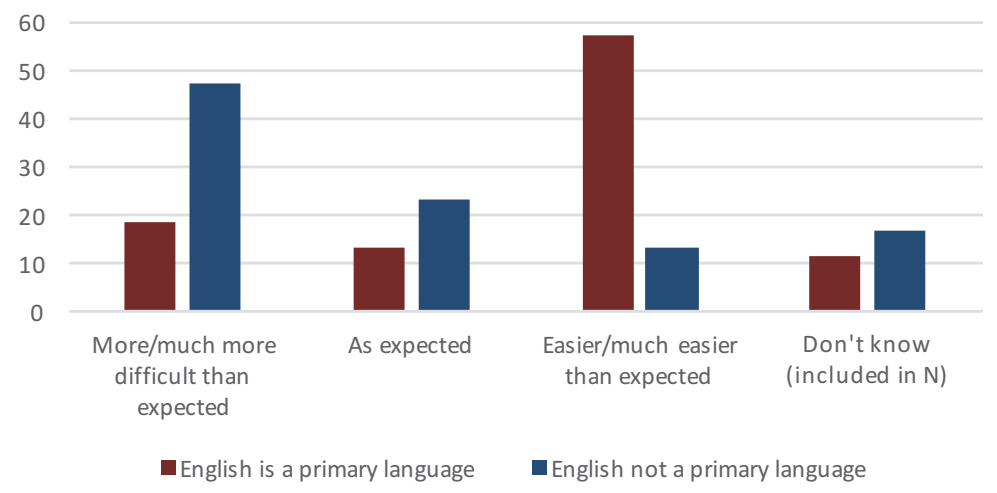

Figure 5.10: Respondents' perceptions of living in Australia by primary language

Source: IMA survey $(n=980)$.

\section{Findings}

One of the most significant findings of the IMA survey is that it clearly shows that IMAs are not a homogenous group. While there may well be some similarities in terms of some specific demographic characteristics, for example in relation to sex, the IMA survey results show that there are very substantial differences in both the demographic characteristics and the experiences of different groups of IMAs. This chapter has highlighted some of the substantial differences in patterns and processes of different IMA groups, mainly by citizenship—-for example, Afghans and Pakistanis reported greater links to Australia prior to travel; Iranians and Sri Lankans 
reported greater involvement of agents who helped them travel (e.g. people smugglers); Iranians tended to travel with family members, while Afghans predominantly travelled without family or friends.

A more nuanced understanding of the very different migration processes experienced by different groups of irregular migrants, including in relation to decision-making, has implications for policy deliberations. For example, the extent and nature of collective decision-making has potential implications for decision-making in relation to the promotion and take-up of assisted voluntary return packages for those found not to be in need of protection. Information on return packages, for example, could also be usefully communicated to others involved in decision-making.

One of the notable differences between citizenship groups was the likelihood of having lived in a host country prior to migrating. Overall, a 'hosted' respondent was typically an Afghan born in Afghanistan, having lived in Pakistan or Iran for many years (with some moving between Afghanistan and their host country), and who was likely to have worked illegally and not have had any contact with UNHCR. These characteristics accord with research on Afghan migration survival strategies, and the tendency of particular groups to engage in circular migratory patterns through the region as a means of economic and cultural survival. Monsutti, for example, has argued that in relation to Hazaras, no hard and fast distinction can be made between refugees and economic migrants and that a 'migration continuum' exists that has developed as part of a broader strategy of survival (Monsutti, 2005, pp. 168-69). Further, he states that 'Afghans give different and usually plural reasons for their decision to migrate: perhaps an outbreak of fighting, a threat from a personal enemy, the danger of bombing or compulsory conscription; perhaps the search for work or opportunities to trade, the need for medical treatment, or the undertaking of a pilgrimage' (2005, p. 146).

For the 'hosted' respondents, it is important to acknowledge that a lack of contact with UNHCR is unlikely to be related to their 'refugeeness' or otherwise. The circumstances in which Afghans live in host countries Iran and Afghanistan and the gradual and systematic reduction in support and assistance to Afghan refugees in Iran and Pakistan over many years will undoubtedly have had an impact on the capacity and/ or willingness of Afghans to seek UNHCR's assistance in host countries. Survey respondents, as IMAs granted protection in the second half of 2011 and calendar year 2012, would have been likely to have travelled prior to 2012, and so a point in time aspect needs to be taken into consideration. 
Another key finding of the survey is that the overwhelming majority of irregular migrants surveyed were motivated by multiple factors. The public discourse about 'economic migrants' and 'genuine refugees' is limited and potentially unhelpful in light of the survey results, which show that a range of factors underpin movement to Australia, such as those related to protection, employment, education services, housing, health services, poverty, corruption, geography and family/community links. The most prominent factors related primarily to protection. This is unsurprising given that the survey population comprised people who travelled as IMAs and had been granted protection in Australia.

Problems facing respondents prior to their departure overwhelmingly related to protection issues. Non-protection problems, such as poverty, corruption, poor education facilities and unemployment were also highlighted by respondents, which is also unsurprising when broader human development issues facing people in some countries of origin are taken into account; an issue that is even more profound for those with marginalised status in host countries (United Nations Development Program [UNDP], 2013).

In terms of reasons for leaving their country of origin and the problems they faced prior to departure, 85 per cent of respondents indicated that both protection and non-protection issues were involved. A much smaller 9 per cent indicated that they had faced or left because of protection issues only. There was a very small proportion of respondents (3 per cent) who indicated that they did not face protection-related problems in their origin country and who indicated that they had left their country of origin for non-protection reasons only.

This would appear to indicate that broader quality of life issues, such as corruption, education services, health services, and lack of economic opportunity, are being considered during decision-making, and are among the factors potential migrants (and their families and others) take into account when assessing and reassessing migration options.

Reasons for leaving as well as reasons for choosing Australia included 'pull factors', most particularly Australia's perceived acceptance of refugees and treatment of asylum seekers. These two factors would appear to be part of decision-making processes as they relate to leaving and choosing a destination, and appeared to be more important than other 'pull' factors (e.g. Australia's economic prosperity). It may be that the distinction between decision-making as it relates to 'leaving' and 'destination' masks 
more complex realities, and that (potential) migrants and their families, are likely to be continually assessing and reassessing their migration options, and that these assessments involve a range of complex interrelated and perhaps conflicting factors that have to be carefully balanced within dynamic environments. That a high proportion of respondents indicated that their migration was 'triggered' by an event or situation resonates with this notion.

It is possible that Monsutti's analysis of Afghan migration as 'partially blurring the boundary between forced migration and voluntary migration' may have wider implications for other groups of people (Monsutti, 2008, p. 73). As the survey has shown, respondents with protection issues are more often than not involved in making decisions about whether to migrate and where to migrate, and their decision-making processes include as well a range of non-protection reasons. This also accords with Neumayer's citing of Efionayi-Mäder et al., that 'such a decision is likely to be the result of a multitude of complex and mutually nonexclusive factors, whose relative importance can differ across origin countries as well as across individuals from the same country of origin' (Neumayer, 2004, p. 163, citing Efionayi-Mäder et al., 2001).

The survey results also highlight the utility of conducting further research on decision-making of potential migrants who decide not to migrate, including in relation to those who may be facing protection issues. Adhikari's research on the impact of a range of factors on potential refugees' decision-making in Nepal highlights that individual decisionmaking, even in extreme conflict situations, is based on more than just the threat to one's life, and includes factors related to economic livelihoods and social networks (Adhikari, 2013).

\section{Conclusions}

As one of the first commissioned research projects undertaken as part of the Irregular Migration Research Program (see Preface and Introduction of this volume for information on the program), and the first quantitative survey of first-hand experiences of IMAs to Australia, the IMA survey provides an empirical evidence-base to assist in the development of improved understanding of decision-making of IMAs to Australia. It is an important addition to the small but growing evidence-base on migrant decision-making. 
The IMA survey results offer insights into a range of areas in which further analysis and research activity would be valuable for creating a solid base of measurement and analysis to inform policy and program considerations. For example, in looking at the differences between how citizenship groups answer questions, future analysis of the final survey results can seek to identify the gaps in our current understanding of the reasons for these differences. This may in turn inform research activities that are tailored to specific citizenship groups.

The findings on the extent to which IMAs access official information and media reporting demonstrate the need for more research into communication networks at the different stages of the journey to Australia, and how information campaigns can be better targeted, including through friends and family in origin countries, to encourage people to not travel to Australia irregularly. Finally, greater understanding of the experiences of IMAs during the transit phase of the journey to Australia could have a significant bearing on bilateral arrangements between destination and transit countries, enabling a greater level of discussion about issues such as voluntary and involuntary returns than perhaps is currently enjoyed.

There is no doubt that as an evidence-base the IMA survey results will be useful and relevant in a number of research areas and in policy deliberations. Ideally, future qualitative research will supplement the survey results, including helping to explain some of the results, particularly as they relate to specific demographic groups.

\section{Reference list}

Adhikari, P. (2013). Conflict induced displacement, understanding the causes of flight. American Journal of Political Science, 57(1), 82-89. doi.org/10.1111/j.1540-5907.2012.00598.x

Bernabe-Ortiz, A., Curioso, W. H., Gonzales, M. A., Evangelista, W., Castagnetto, J. M., Carcamo, C. P., ... Holmes, K. K. (2008). Handheld computers for self-administered sensitive data collection: A comparative study in Peru. BMC Medical Informatics and Decision Making, 8(11), n. p. doi.org/10.1186/1472-6947-8-11 
Bowling, A. (2005). Mode of questionnaire administration can have serious effects on data quality. Journal of Public Health, 27(3), 281-91. doi.org/10.1093/pubmed/fdi031

Brekke, J.-P., \& Aarset, M. F. (2009). Why Norway? Understanding asylum destinations. Oslo: Institutt for Samfunnsforskning (Institute for Social Research).

Castles, S. (2013). The forces driving global migration. Journal of Intercultural Studies, 34(2), 122-40. doi.org/10.1080/07256868.201 3.781916

de Haas, H. (2010). Migration transitions: a theoretical and empirical inquiry into the developmental drivers of international migration. Oxford: International Migration Institute.

de Haas, H. (2011). The determinants of international migration: conceptualizing policy, origin and destination effects. Working Paper 32. Oxford: International Migration Institute.

Doraï, M. (2011). Iraqis in exile: Migratory networks as a coping strategy. International Journal of Contemporary Iraqi Studies, 5(2), 215-29. doi.org/10.1386/ijcis.5.2.215_1

Efionayi-Mäder, D., Chimienti, M., Dahinden, J., \& Piguet, E. (2001). Asyldestination Europa: eine Geographie der Asylbewegungen. Zurich: Seismo-Verlag.

Fussell, E., \& Massey, D. (2004). The limits of cumulative causation: international migration from Mexican urban areas. Demography, 41(1), 151-72. doi.org/10.1353/dem.2004.0003

Hamlin, R. (2012). International law and administrative insulation: A comparison of refugee status determination regimes in the United States, Canada and Australia. Law \& Social Inquiry, 37(4), 933-68. doi.org/10.1111/j.1747-4469.2012.01292.x

Hatton, T. J. (2011). Seeking asylum-Trends and policies in the OECD. London: Centre for Economic Policy Research.

Havinga, T., \& Böcker, A. (1999). Country of asylum by choice or by chance: Asylum seekers in Belgium, the Netherlands and the UK. Journal of Ethnic and Migration Studies, 25(1), 43-61. doi.org/10.108 0/1369183X.1999.9976671 
Hox, J., Kef, S., \& de Leeuw, E. (2003). Computer assisted selfinterviewing tailored for special populations and topics. Field Methods 15(3), 223-51.

Jewkes, R., Sikweyiya, Y., Morrell, R., \& Dunkle, K. (2009). Understanding men's health and use of violence: Interface of rape and HIV in South Africa. Pretoria: South African Medical Research Council.

Johansson, R. (1990). The refugee experience in Europe after World War II: Some theoretical and empirical considerations. In G. Rystad (Ed.), The uprooted: Forced migration as international problem in the post-war era (pp. 227-69). Lund: Lund University Press.

Jones, M. (2009). Refugee status determination: three challenges. Forced Migration Review, 32, n.p. Retrieved from www.fmreview.org/ statelessness/jones.html.

Koser, K. (1997). Social networks and the asylum cycle: The case of the Iranians in the Netherlands. The International Migration Review, 31(3), 591-611.

Koser, K. (2008). Why migrant smuggling pays. International Migration, 46(2), 3-26. doi.org/10.1111/j.1468-2435.2008.00442.x

Koser, K. (2011). Why take the risk? Explaining migrant smuggling. In T. Modood, \& Salt, J. (Eds), Global migration, ethnicity and Britishness (pp. 65-84). London: Palgrave. doi.org/10.1057/ 9780230307155_4

Koser, K., \& McAuliffe, M. (2013). Establishing an evidence-base for future policy developmenton irregularmigration to Australia. Irregular Migration Research Program, Occasional Paper Series 01. Canberra: Australian Department of Immigration and Citizenship. Retrieved from www.border.gov.au/ReportsandPublications/Documents/research/ evidence-base-for-future-policy.pdf.

Koser, K., \& Pinkerton, C. (2002). The social networks of asylum seekers and the dissemination of information about the countries of asylum. London: Research Development and Statistics Directorate, UK Home Office. 
McAuliffe, M. (2013). Seeking the views of irregular migrants: Survey background, rationale and methodology. Irregular Migration Research Program, occasional paper series 04, Department of Immigration and Border Protection. Retrieved from www.border.gov.au/Reports andPublications/Documents/research/views-irregular-migrantbackground-rationale-methodology.pdf.

Middleton, D. (2005). Why asylum seekers seek refuge in particular destination countries: an exploration of key determinants. Global Migration Perspectives no. 34. Global Commission on International Migration.

Monsutti, A. (2005). War and migration: Social networks and economic strategies of the Hazaras of Afghanistan. New York and London: Routledge.

Monsutti, A. (2008). Afghan migratory strategies and the three solutions to the refugee problem. Refugee Survey Quarterly, 27(1), 58-73. doi.org/10.1093/rsq/hdn007

Monsutti, A. (2010). The transnational turn in migration studies and the Afghan social networks. In Chatty, D., \& Finlayson, B. (Eds), Dispossession and displacement: Forced migration in the Middle East and North Africa. Oxford and New York: Oxford University Press.

Neumayer, E. (2004). Asylum destination choice: What makes some West European countries more attractive than others? European Union Politics, 5(2), 155-80. doi.org/10.1177/1465116504042444

Robinson, V., \& Segrott, J. (2002). Understanding the decision making of asylum seekers. Home Office research study 243. London: Home Office Research, Development and Statistics Directorate.

Sayer, R. A. (1992). Method in social science: A realist approach (2nd ed.). London: Routledge.

Seebregtsa, J. C., Zwarenstein, M., Mathews, C., Fairall, L., Flisher, A. J., Seebregtse, C., ... Klepp, K. I. (2009). Handheld computers for survey and trial data collection in resource-poor settings: Development and evaluation of PDACT, a Palm Pilot interviewing system. International Journal of Medical Informatics 78 (11), 721-31. 
Spinks, H. (2013). Destination anywhere? Factors affecting asylum seekers' choice of destination country. Research paper no. 1, Parliamentary Library. Canberra: Australian Government.

Thielemann, E. (2006). The effectiveness of governments' attempts to control unwanted migration. In Parsons, C. A., \& Smeeding, T. M. (Eds), Immigration and the Transformation of Europe (442-72). Cambridge: Cambridge University Press. doi.org/10.1017/cbo 9780511493577.017

Toshkov, D. (2012). The dynamic relationship between asylum applications and recognition rates in Europe (1987-2010). European Union Politics, 15(2), 192-214. doi.org/10.1177/1465116513511710

Tourangeau, R., \& Smith, T. W. (1996). Asking sensitive questions: the impact of data collection mode, question format and question context. Public Opinion Quarterly 60(2), 275-304. doi.org/10.1086/297751

United Nations Development Program. (2013). The Rise of the South: Human Progress in a Diverse World. Human Development Report 2013. New York: Author.

United Nations High Commissioner for Refugees. (2013). Displacement: The New 21st Century Challenge. Global Trends 2012. Geneva: Author.

van Liempt, I., \& Doomernik, J. (2006). Migrant's agency in the smuggling process: The perspectives of smuggled migrants in the Netherlands. International Migration, 44(4), 165-90. doi.org/10.1111/j.14682435.2006.00383.x

Zimmerman, K. (1996). European migration: Push and pull. International Regional Science Review, 19(1-2), 95-128. doi.org/ 10.1177/016001769601900211 
This text is taken from A Long Way to Go: Irregular Migration Patterns, Processes, Drivers and Decision-making, edited by Marie McAuliffe and Khalid Koser, published 2017 by ANU Press, The Australian National University, Canberra, Australia.

dx.doi.org/10.22459/LWG.12.2017.05 